\title{
レチノイン酸によるループス腎炎の治療
}

\author{
木下浩二，船内正憲
}

\section{Therapeutic effect of retinoic acid in lupus nephritis}

\author{
Koji KINOSHITA and Masanori FUNAUCHI
}

Department of Nephrology and Rheumatology, Kinki University Faculty of Medicine, Osaka-Sayama, Osaka Japan

(Received October 17, 2011)

\section{summary}

Lupus nephritis is a major cause of morbidity and mortality among patients with systemic lupus erythematosus (SLE). In these patients, treatment with immunosuppressive agents can significantly improve the outcome of lupus nephritis. However, these agents have severe adverse reactions and some patients are refractory to those therapies. Retinoids, a group of natural and synthetic derivatives of vitamin A, play important regulatory roles of cellular proliferation, differentiation and apoptosis. They have been used for the treatment of acute promyelocytic leukemia and inflammatory disorders such as psoriasis and acne. It has also been shown that retinoids have therapeutic effects in various animal models of kidney disease, including lupus nephritis. Based on these findings, retinoids are a promising agent for the treatment of lupus nephritis. We studied the clinical effects of retinoid therapy in patients with lupus nephritis. In open clinical trial, 7 patients with active lupus nephritis that was refractory to steroid therapy were studied. In all these patients, retinoid was added to the immunosuppressive therapy and its therapeutic effects were evaluated. As a result, 4 out of 7 patients showed improvement of the clinical symptoms and laboratory findings, including urinary protein and anti-dsDNA antibody levels. No important adverse effects of ATRA therapy were observed in all patients. Thus, retinoids might be indicated in cases of lupus nephritis that are refractory to conventional immunosuppressive therapy.

Key words_lupus; retinoid; nephritis

抄 録

ループス腎炎は，全身性エリテマトーデス（SLE）の主要な臓器障害であり生命予後に大きな影響を与えている. その治療には副腎皮質ステロイド薬やシクロフォスファミドなどの免疫抑制薬を使用し一定の効果をあげている が，しばしばそれらの副作用等により治療に難渋することがある、レチノイン酸は，ビタミン Aの誘導体の総称 であるが，細胞の分化増殖やアポトーシスに重要な役割を演じていることが知られている. 以前から抗腫瘍効果に 注目され急性前骨髄性白血病の治療に用いられているが，近年，レチノイン酸の持つ免疫調節作用を利用して，種 々の動物モデルを用いた研究に挍いて自己免疫疾患や腎疾患にも治療効果を示すことが明らかになってきた．SLE においても，その自然発症モデルであるNZB/WF1 マウスにレチノイン酸を投与することにより，生存期間を著 明に延長させるとともに，蛋白尿の抑制，腎組織障害の改善効果が報告されている．さらに活動期ループス腎炎症 例に対する臨床試験では 7 例中 4 例にネフローゼ症状および血清免疫学的異常の改善を認め, また重篤な副作用を 認めなかったことから，レチノイン酸がループス腎炎の新しい治療薬となり得ることが示唆された.

\section{はじめに}

全身性エリテマトーデス（SLE）は，腎臓を含め た全身の諸㵴器を侵す代表的な自己免疫疾患であ り，その発症には，抗 DNA 抗体をはじめとする自 己抗体や自己反応性リンパ球, サイトカインバラン スの不均衡などの免疫調節異常が密接に関与してい

近畿大学医学部腎臓膠原病内科
る.SLEの治療としてはこれらの自己免疫異常を 是正するための副腎皮質ステロイド薬, シクロフォ スファミドなどを用いた免疫抑制療法が行われ，一 定の効果をあげているが，ときに易感染性や悪性腫 瘍の誘発といった重篤な副作用により治療に難渋す ることがあり，より効率的に免疫異常を是正し副作 用の少ない治療薬が待ち望まれている. 近年, ビタ ミン A の誘導体であるレチノイン酸が免疫調節作 用を持ち, 自己免疫疾患の治療薬としての可能性が 
示唆されている1). 本稿では, SLEの代表的蔵器障 害であるループス腎炎に対するレチノイン酸の治療 効果について，今までの報告に加えわれわれの最近 の知見についても紹介する.

$$
\text { レチノイン酸 }
$$

レチノイン酸（retinoic acid: RA）はビタミンA の誘導体の総称であり, all-trans-RA (ATRA), 9cis-RA (alitretinoin) や 13-cis-RA (isotretinoin) があり，核内に存在するレチノイン酸受容体 retinoic acid receptor (RAR) や retinoic $\mathrm{X}$ receptor （RXR）々特異的に結合し，核内転写因子を調節す ることにより生体内に抢いて細胞の分化増殖，アポ トーシス, 組織発生, 恒常性の維持に重要な役割を 果たしている2。臨床に扔いてレチノイン酸は，以 前よりその抗腫瘍効果に注目され，急性前骨髄球性 白血病の治療薬3 や乾癬やざ瘡などの皮膚疾患に使 われている4,5)。 また，ビタミン $\mathrm{A}$ 欠損マウスを用 いた研究で, ビタミン A が Th1 免疫応答を抑制し, Th2 応答が促進することや1)，さらにレチノイン酸 が Th1への分化を抑制するといった ，レチノイン 酸の持つ免疫調節作用により自己免疫疾患に対する 新たな治療薬となることが期待されるようになって きた。

\section{レチノイン酸と自己免疫疾患}

レチノイン酸は未だ臨床現場では自己免疫疾患の 治療薬としては確立されていないが，いくつかの実 験モデル動物の研究において有効性が示されてい る。例えば，多発性硬化症のモデルである実験的ア レルギー性脳脊髄炎（EAE）は，疾患惹起性 $\mathrm{T}$ 細 胞は Th1 タイプであり, レチノイン酸の投与によ り, Th1/Th2 バランスを Th2 優位の状態に変化さ せ $\mathrm{EAE} の$ 発症を抑制することが報告されてい る7). またコラーゲン誘発関節炎（CIA）において も, レチノイン酸は TNF- $\alpha, \mathrm{IL}-6$ などのサイトカ イン産生を抑制し関節炎の発症増悪を抑制した ${ }^{8)}$.

\section{レチノイン酸と腎疾患}

レチノイン酸はさまざまな実験的腎疾患モデルに 対しても予防的，打よび治療的効果を有すことが報 告されている.メサンギウム増殖性腎炎のモデルで ある Thy1.1 系球体腎炎では, レチノイン酸はメサ ンギウム細胞のオステオポンチン，フィブロネクチ ン, MCP-1, iNOS などの発現を抑え，その増殖を
抑制することにより腎炎の発症を抑制する ${ }^{9,10)}$ 。 た微小変化型腎症のモデルであるPuromycin aminonucleoside（PAN）腎症はポドサイトの障害 によるネフローゼ症候群が特徵であるが，レチノイ ン酸の投与によりPANで誘導される足突起のアポ トーシスを抑制するとともに MCP-1 やフィブロネ クチンの発現を抑え，間質への細胞浸潤も抑制する ことによりネフローゼが改善される11).さらに，一 側尿管結柇（UUO）モデルでは, MCP-1, TGF$\beta 1, \mathrm{I}$ 型コラーゲンなどの発現を抑えることにより 腎間質の線維化を抑制した ${ }^{12)}$.

\section{ループスモデルマウスに対するレチノイン酸の治療 効果}

NZB/WF1 マウスは, SLE の代表的モデルマウ スであり，生後 5 か月齢から自然産生される抗 DNA 抗体を含む多彩な自己抗体や自己反応性リン パ球を介して, ヒトループス腎炎に酷似した免疫複 合体型糸球体腎炎を発症し，腎不全のために死亡す る(50\%生存率約 8 か月). その病態には, IL-4, IL-6, IL-10 等の Th2 サイトカインのみならず, IFN- $\gamma$ や IL-2 などの Th1 サイトカインも重要な役 割を演じているとされる13 16).

われわれはループスモデルマウスに対するレチノ イン酸の治療効果を検討する目的で以下の実験を行 った17). 3 か月齢の NZB/WF1 マウスを 2 群に分 け，一方には ATRA $0.5 \mathrm{mg}$ を，もう一方には生理 食塩水（コントロール）を週 3 回，7 か月間腹腔内 投与した $(\mathrm{n}=8)$. その結果，ATRA 投与群は，コ ントロール群に比べ有意に生存率が延長し, 投与 7 か月後（10 か月齢時）コントロール群では 8 匹中 3 匹 $(37.5 \%)$ が生存しているの久であったのに対し ATRA 投与群では 8 匹中 6 匹 $(75 \%)$ が生存して

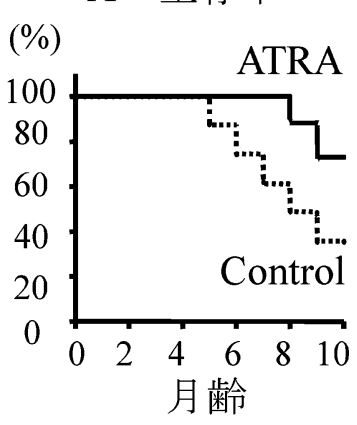

B 蛋白尿出現率

図 1 ATRA 投与群とコントロール群の生存率, 蛋白尿出現 率の比較 文献 ${ }^{17)}$ より引用改変.

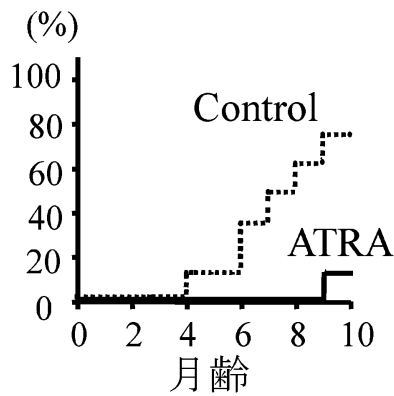


コントロール群ＡTRA投与群

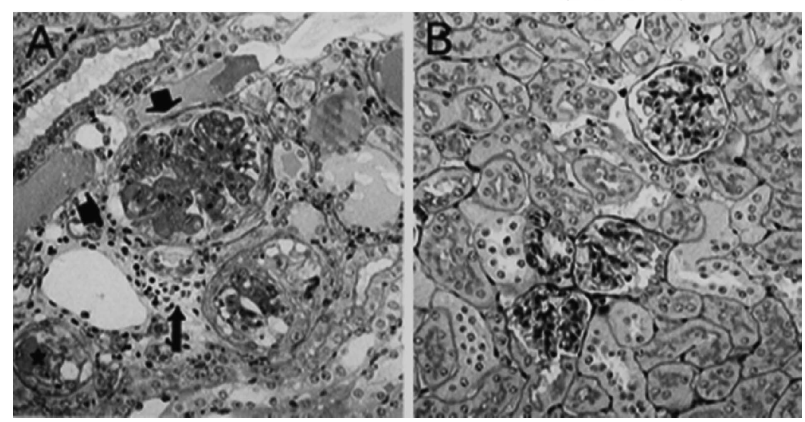

図 2 マウス腎組織の比較. A, コントロール群; 免疫複合 体型腎炎像を示す。硬化した系球体（太い矢印），変 性した尿細管 (星印), 炎症細胞浸潤 (細い矢印)。B, ATRA 投与群 ; ほぼ正常の腎組織像を示す。文献 ${ }^{17)}$ 上 り引用改変

いた（図 1A）。さらに腎障害の指標である蛋白尿 の出現率をみると, コントロール群では 4 か月齢で 蛋白尿が出現し始め，10 か月齢では 75\%のマウス で陽性になるのに対し, ATRA 投与群では有意に 蛋白尿の出現率が抑制され，10 か月齢で $12.5 \%$ の マウスが陽性になるのみであった（図1B）。また病 理組織学的検索の結果, いずれのマウスも死因は腎 不全と考えられた。この結果から, ATRAがルー プス腎炎の発症を抑制することにより，NZB/WF1 マウスの生存率を改善させることが示唆された。

さらに両群 $(8$ か月齢 $)$ の腎組織を免疫病理学的 に検討した. NZB/WF1 マウスにみられるループス 腎炎の組織学的特徵は, いわゆる免疫複合体型腎炎 であり, 糸球体メサンギウム基質の肥厚, 細胞増生 や係蹄毛細血管壁の肥厚 (wire-loop 病変), 間質の 細胞浸潤, 尿細管の萎縮, 変性が認められ, また蛍 光抗体法で糸球体に $\mathrm{IgG}$ 抢よび補体の顆粒状沈着 が認められることが知られている.コントロール群 の腎組織像も, 典型的な免疫複合体型腎炎像を示 し, 炎症細胞浸潤が多数認められるのに対し（図 2A), ATRA 投与群では, 腎糸球体, 尿細管, 間質 は正常に近いものであり, 細胞浸潤も認めなかった (図 2B). 同様に, 蛍光抗体法でも ATRA 投与群で はコントロール群に比べて, 系球体の IgG 沈着が 有意に抑制されていた。

NZB/WF1 マウスでは，抗 DNA 抗体がループス 腎炎の発症, 増悪に密接に関連していることから, ATRA が NZB/WF1 マウスの抗 DNA 抗体産生に およぼす影響を比較検討した。両群（8か月齢）の マウスから血清を採取し ELISA 法により抗 DNA 抗体価を測定した結果, ATRA 投与群では, コン
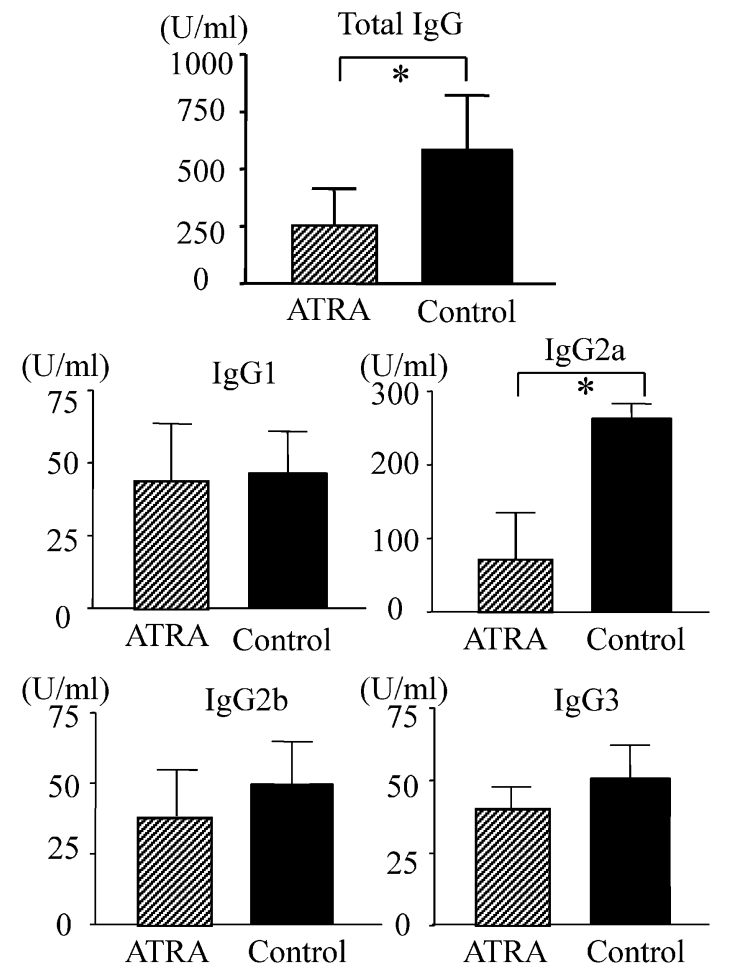

図 3 ATRA 投与群とコントロール群の抗 DNA 抗体価の比 較 $\mathrm{p}<0.05$. 文献 ${ }^{17)}$ より引用改変.
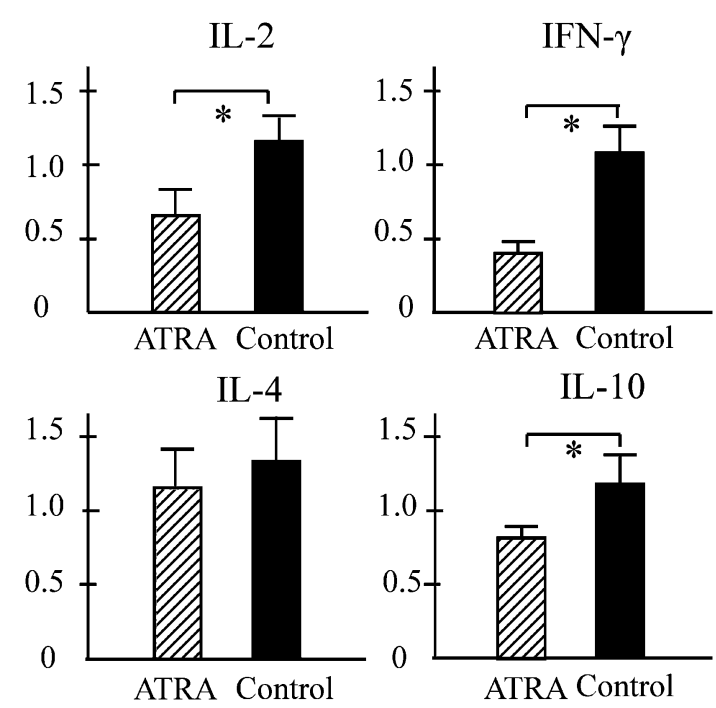

IL-10

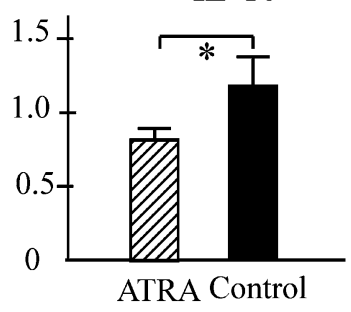

図 4 ATRA 投与群とコントロール群のサイトカイン発現量 の比較

$\mathrm{p}<0.05$.

文献 ${ }^{17)}$ より引用改変.

トロール群に比べ, 全 IgG 抗 DNA 抗体抢よび IgG2a 抗 DNA 抗体産生を有意に抑えた（図 3).

さらに, ATRA が NZB/WF1 マウス脾臓 CD4 T 細胞のサイトカイン発現に与える影響の有無を検討 した．両群のマウスから脾臓 CD4 T 細胞を採取し, RT-PCR 法により Th1 サイトカイン (IL-2, IFN- $\gamma$ ), Th2 サイトカイン (IL-4, IL-10) の発現量を比較 
した（図 4)。従来の報告では, レチノイン酸は $\mathrm{T}$ 細胞による Th1 サイトカインの産生を抑制すると されている18 20). 今回の我々の結果からも, ATRA は T 細胞による Th1 サイトカインの産生, 特に IFN- $\gamma$ を強く抑制し, IgG2a アイソタイプの 抗 DNA 抗体の産生を抑制した。 IFN- $\gamma$ は NZB/ WF1 マウスの自己免疫病態に重要な役割を果たし ていることが知られている21,22)。 また IFN- $\gamma$ は IgMをIgG2a にクラススイッチさせる働きも持つ が，IgG2a 抗 DNA 抗体は NZB/WF1 マウスにおい て腎炎発症に密接に関係しているといわれてい る23)。このことから，ATRA は IFN- $\gamma$ の発現を抑 制することにより，IgG2a 抗 DNA 抗体の産生，さ らに腎系球体の IgG2a の沈着を抑え，その結果， 重篤な免疫複合体型腎炎の発症を防いだものと考え られた。

以上より ATRA 投与により NZB/WF1 マウスの 生存率および腎炎の改善を認めたが，ATRAによ る Th1 細胞の機能の抑制がその一因であることが 示唆され，SLEの病態ならびに治療法を開発する 上で非常に有意義な知見であると考えられた.

さらにわれわれは臨床応用に先立ち，ループス腎 炎の治療においてレチノイン酸が実際に副腎皮質ス テロイド薬との相乗効果およびステロイド薬の減量 効果があるのかをループスモデルマウスにレチノイ ン酸とステロイド薬を併用投与して検討した ${ }^{24)}$ 。そ の結果単独ではそれほどの治療効果を表わさない程 度の少量のレチノイン酸であってもステロイド薬と 併用することにより著明に抗 DNA 抗体産生, 炎症 性サイトカイン産生, 腎組織障害を是正し, 生存率 および蛋白尿を改善しうることが示されレチノイン 酸がヒトループス腎炎の治療薬として有用である可 能性が示唆された.

\section{レチノイン酸のループス腎炎治療への臨床応用}

ステロイド抵抗性のループス腎炎に対するレチ， イン酸の有効性, 安全性を検討する目的で表 1 に示 す選択基準，除外基準を満たす 7 例の SLE 患者に 本人の承諾を得た上でATRA を投与した。尚，本

表 1

\begin{tabular}{|c|c|}
\hline 対象疾患 & $\begin{array}{l}\text { SLEの診断（分類）基準（ACR）により SLE } \\
\text { と診断されたループス腎炎患者 }\end{array}$ \\
\hline 選択基準 & $\begin{array}{l}\text { 1. } 18 \text { 歳以上 } \\
\text { 2. プレドニゾロン換算 } 10 \mathrm{mg} \text { 以上のステロイ } \\
\text { ド薬が投与され, 次のいずれも該当する患 } \\
\text { 者 } \\
\text { (1) 一日尿蛋白量 } 0.5 \mathrm{~g} \text { 以上 } \\
\text { (2) 免疫学的活動性を有する患者 } \\
\text { a. 抗 } \mathrm{dsDNA} \text { 抗体価 }>10 \mathrm{IU} / \mathrm{ml} \\
\text { b. 補体 } \mathrm{CH} 50<30 \mathrm{U} / \mathrm{ml} \\
\text { 3. 治験への参加について本人より同意の得ら } \\
\text { れた患者 }\end{array}$ \\
\hline 除外基準 & $\begin{array}{ll}\text { 1. } & \text { 妊娠中または妊娠を希望する女性 } \\
\text { 2. } & \text { 肝機能障害を有する患者 } \\
\text { 3. 高脂血症を有する患者 } \\
\text { 4. } \\
\text { 本剤投与開始前 } 8 \text { 週以内にステロイド薬の } \\
\text { 増量など尿蛋白に影響を与える薬剤の投与 } \\
\text { を行った患者 } \\
\text { 5. 糖尿病 }(\mathrm{HbA} 1 \mathrm{c}>8 \%) \text { を有する患者 } \\
\text { 6. 血清クレアチニンが } 1.5 \mathrm{mg} / \mathrm{d} 1 \text { 以上の患者 }\end{array}$ \\
\hline
\end{tabular}

表 2 患者背景

\begin{tabular}{rrrrcc}
\hline \hline $\begin{array}{c}\text { 患者 } \\
\text { No }\end{array}$ & 性別 & 年齢 & $\begin{array}{c}\text { 罹病期間 } \\
\text { (年) }\end{array}$ & $\begin{array}{c}\text { 腎生検 } \\
\text { (WHO 分類) }\end{array}$ & $\begin{array}{c}\text { ステロイド } \\
\text { 投与量 } \\
\text { (PSL 換算 }\end{array}$ m) \\
\hline 1 & 女性 & 47 & 1 & $\mathbb{N}$ & 20 \\
2 & 女性 & 38 & 4 & $\mathbb{N}$ & 30 \\
3 & 女性 & 37 & 2 & $\mathbb{N}$ & 12.5 \\
4 & 女性 & 27 & 7 & $\mathbb{N}$ & 35 \\
5 & 女性 & 31 & 15 & - & 15 \\
6 & 女性 & 28 & 9 & - & 25 \\
7 & 女性 & 59 & 23 & - & 10 \\
\hline
\end{tabular}

表 3 ATRA 治療開始時検査データ

\begin{tabular}{|c|c|c|c|c|c|c|}
\hline $\begin{array}{l}\text { 患者 } \\
\text { No }\end{array}$ & $\begin{array}{l}\text { 蛋白尿 } \\
(\mathrm{g} / \text { 日) }\end{array}$ & $\begin{array}{l}\text { 厡潜血 } \\
\text { (毎視野) }\end{array}$ & $\begin{array}{c}\text { 血清アルブミン } \\
(\mathrm{g} / \mathrm{dl})\end{array}$ & $\begin{array}{c}\text { 血清クレアチニン } \\
\text { (mg/dl) }\end{array}$ & $\begin{array}{l}\text { 抗 DNA 抗体 } \\
(\mathrm{U} / \mathrm{ml})\end{array}$ & $\begin{array}{l}\text { 補 体 } \\
(\mathrm{CH} 50)\end{array}$ \\
\hline 1 & 2.7 & $30 \sim 49$ & 2.5 & 0.76 & 13 & 29 \\
\hline 2 & 6.4 & $>100$ & 2.5 & 0.59 & 13 & 20 \\
\hline 3 & 0.6 & $1 \sim 4$ & 3.8 & 0.76 & 70 & 21 \\
\hline 4 & 6.2 & $>100$ & 1.7 & 0.55 & 5 & 28 \\
\hline 5 & 3.0 & $1 \sim 4$ & 4.0 & 0.95 & 24 & 25 \\
\hline 6 & 5.9 & $1 \sim 4$ & 1.8 & 1.11 & 70 & 27 \\
\hline 7 & 1.5 & $1 \sim 4$ & 4.0 & 0.64 & 18 & 14 \\
\hline
\end{tabular}


臨床試験は近畿大学医学部倫理委員会の承諾を得た ものである. 対象症例 7 例の患者背景は, 全員が女 性，平均年齢は 34.8 歳，平均罹病期間は $8.7 \pm 7.8$ 年, 腎生検の所見は施行した 4 例すべて WHO-IV 型，平均ステロイド投与量はプレドニゾロン (PSL) 換算で $20.7 \pm 9.8 \mathrm{mg}$ であった（表 2)。また，治療 開始時の検査データは表 3 のとおりである.この活 動性ループス腎炎患者 7 症例に対し ATRA（トレ チノイン） $10 \mathrm{mg}$ を 1 日 1 回 6 ヶ月間投与し，表 4 に示す観察項目を比較検討した. その結果, 投与し た 7 例中 4 例にネフローゼ症候群の効果判定基準の 完全寛解に達するとともにいずれの観察項目におい ても改善傾向を認めた（表 5, 図 5). 残り 3 例は効 果不十分にて投与 3 ヶ月で中止となった。 ATRA による肝機能障害, 脂質代謝異常, 精神症状, 皮膚 症状を含む重篤な副作用はいずれの症例においても 認められなかった。ATRA 著効例の臨床経過を図 6 に示す 25). 症例は 47 歳女性. 1997 年顔面紅斑, 抗 核抗体，抗 DNA 抗体，リンパ球減少を認めたため SLE と診断し経過観察していた。2006 年 4 月下肢 浮腫が出現したため, 腎生検を行いループス腎炎

表 4 評価項目
1. 蛋白尿（g/日）
2. 尿潜血 (/毎視野)
3. 血清アルブミン $(\mathrm{g} / \mathrm{dl})$
4. 血清クレアチニン $(\mathrm{mg} / \mathrm{dl})$
5. 抗 DNA 抗体 $(\mathrm{U} / \mathrm{ml})$
6. 補体 $(\mathrm{CH} 50)$

（WHO-IV）と診断し PSL を増量投与するも改善 せず，レチノイン酸の経口投与を開始したところ， 急速に蛋白尿の軽減, 血清蛋白の増加抢よび抗 DNA 抗体, 補体価の改善を認めた.

$$
\text { ま と め }
$$

ループス腎炎モデルを含めた自己免疫疾患, 腎疾 患モデル動物に対するレチノイン酸の抗炎症効果が 解明されつつある. それによれば従来の免疫抑制薬 とは違った作用機序を持つことから，これまで治療 抵抗性であったり副作用等のため治療に難渋した症 例に対する次の一手として大いに期待が持てそうで ある．実際，活動期ループス腎炎症例に投与したと ころ 7 例中 4 例にネフローゼ症状および血清免疫学 的異常の改善を認め, また重篤な副作用を認めなか った. 今後さらに症例数が増え, 詳細な検討が加え られることにより，レチノイン酸がループス腎炎の 新しい選択枝の一つとなることを期待して稿を終え る.

表 5 腎疾患アウトカム

\begin{tabular}{ccc}
\hline \hline $\begin{array}{c}\text { 患者 } \\
\text { No }\end{array}$ & $\begin{array}{c}\text { ATRA } \\
\text { 継続症例 }\end{array}$ & $\begin{array}{c}\text { ATRA 中断症例 } \\
\text { (投与月数 })\end{array}$ \\
\hline 1 & 完全寛解 & \\
2 & 完全寛解 & \\
3 & & 不応例 $(3$ ヶ月 $)$ \\
4 & 完全寛解 & \\
5 & 完全寛解 & \\
6 & & 不応例 $(3$ ヶ月 $)$ \\
7 & & 不応例 $(3$ ヶ月 $)$ \\
\hline
\end{tabular}
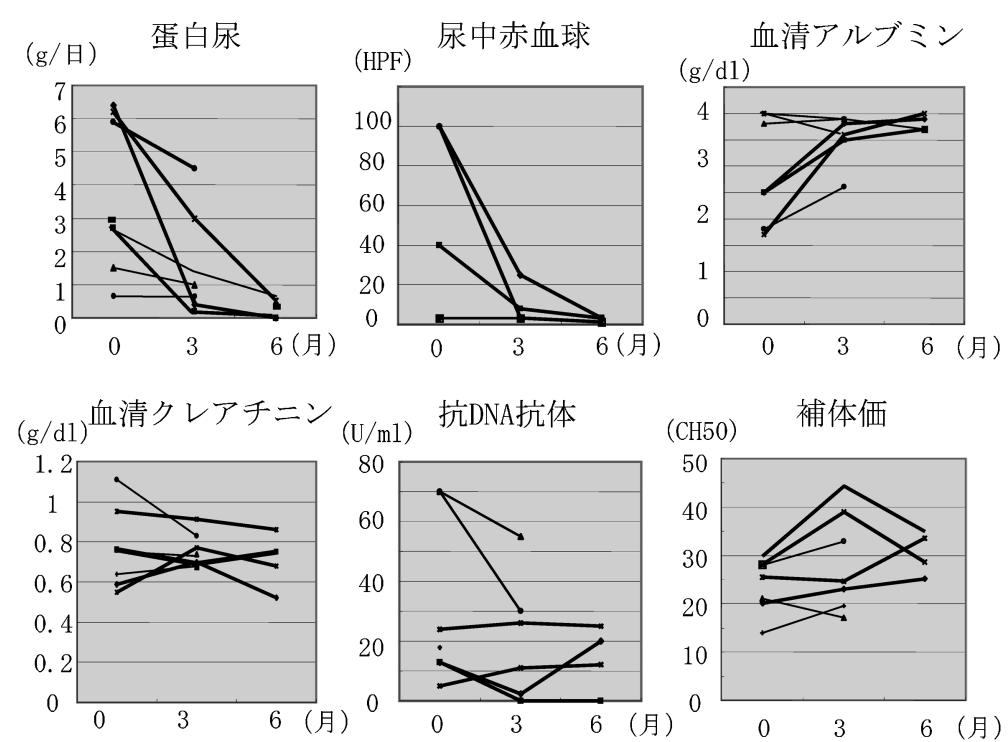

図 5 各観察項目の推移 


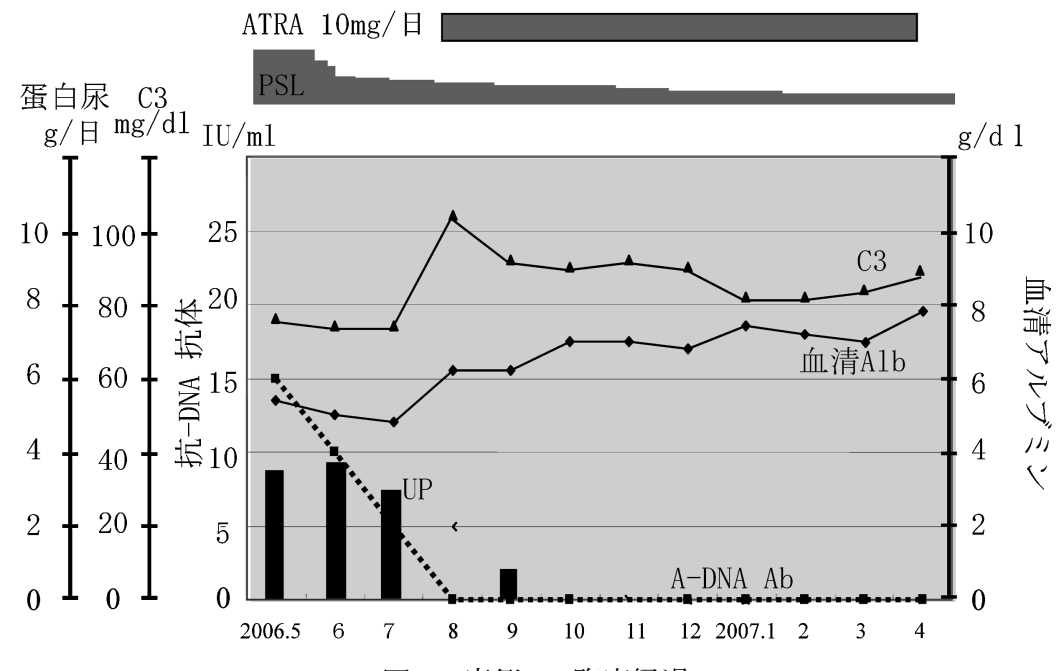

図 6 症例 1 臨床経過

\section{文献}

1) Cantorna, M. T., et al. : In vitamin A deficiency multiple mechanisms establish a regulatory $\mathrm{T}$ helper cell imbalance with excess Th1 and insufficient Th2 function. J. Immunol. 152 : 1515-1522, 1994.

2）深澤弘志，ほか：レチノイドによる自己免疫 疾患の治療. 日本臨床免疫学会会誌 29 : 114126, 2006.

3) Huang, M. E., et al. : Use of all-trans retinoic acid in the treatment of acute promyelocytic leukemia. Blood. 72 : 567-572, 1988.

4) Ward, A. et al. : Etretinate : a review of its pharmacological properties and therapeutic efficacy in psoriasis and other skin disorders. Drugs. 26 : 9-43, 1983.

5) Peck, G. L., et al. : Isotretinoin versus placebo in the treatment of cystic acne : a randomized double-blind study. J. Am. Acad. Dermatol. 6 : 735-745, 1982.

6) Iwata, M., et al. : Retinoic acids exert direct effects on $\mathrm{T}$ cells to suppress Th1 development and enhance $\mathrm{Th} 2$ development via retinoic acid receptors. Int. Immunol. 15 : 1017-1025, 2003.

7) Racke, M. K., et al. : Retinoid treatment of experimental allergic encephalomyelitis. IL-4 production correlates with improved disease course. J. Immunol. 154 : 450-458, 1995.

8) Nozaki, Y., et al. : Anti-inflammatory effect of all-trans-retinoic acid in inflammatory arthritis. Clinical Immunology. 119 : 272-279, 2006.

9) Wagner. J., et al. : Retinoic acid reduces glomerular injury in a rat model of glomerular damage. J. Am. Soc. Nephrol. 11 : 1479-1487,
2000.

10) Lehrke, I., et al. : Retinoid receptor-specific agonists alleviate experimental glomerulonephritis. Am. J. Physiol. Renal Physiol. 282 : 741-751, 2002.

11) Moreno-Manzano, V., et al. : Retinoids as a potential treatment for experimental puromycin-induced nephrosis. Br. J. Pharmacol. 139 : 823-831, 2003.

12) Kishimoto, K., et al. : Therapeutic Effect of Retinoic Acid on Unilateral Ureteral Obstruction Model. Nephron Exp. Nephrol. 118 : e69e78, 2011.

13) Finck, B. K., et al. : Interleukin 6 promotes murine lupus in NZB/NZW F1 mice. J. Clin. Invest. 94 : 585-591, 1994.

14) Santiago, M. L., et al. : Interleukin-4 protects against a genetically linked lupus-like autoimmune syndrome. J. Exp. Med. 185:65-70, 1997.

15) Takahashi, S., et al. : Imbalance towards Th1 predominance is associated with acceleration of lupus-like autoimmune syndrome in MRL mice. J. Clin. Invest. 97 : 1597-1604, 1996.

16) Nakajima, A., et al. : Roles of IL-4 and IL-12 in the development of lupus in NZB/W F1 mice. J. Immunol. 158 : 1466-1472, 1997.

17) Kinoshita, K., et al. : Retinoic acid reduces autoimmune renal injury and increases survival in NZB/W F1 mice. J. Immunol. 170 : 5793-5798, 2003.

18) Felli, M. P., et al. : Retinoic acid-induced down-regulation of the interleukin-2 promoter via cis-regulatory sequences containing an octamer motif. Mol. Cell. Biol. 11 : 4771-4778, 
1991.

19) Cippitelli, M., et al. : Retinoic acid-induced transcriptional modulation of the human interferon- $\gamma$ promoter. J. Biol. Chem. 271 : 2678326793, 1996.

20) Cantorna, M. T., et al. : Vitamin A down-regulation of IFN $-\gamma$ synthesis in cloned mouse Th1 lymphocytes depends on the CD28 costimulatory pathway. J. Immunol. $156: 2674-2679$, 1996.

21) Schwarting, A., et al. : IFN- $\gamma$ receptor signaling is essential for the initiation, acceleration, and destruction of autoimmune kidney disease in MRL-Fas ${ }^{\mathrm{lpr}}$ mice. J. Immunol. 161:494503, 1998.

22) Ozmen, L., et al. Experimental therapy of systemic lupus erythematosus: the treatment of
NZB/W mice with mouse soluble interferongamma receptor inhibits the onset of glomerulonephritis. Eur. J. Immunol. 25 : 612, 1995.

23) Park, C. L., B et al. : Isotypic profiles and other fine characteristics of immune responses to exogenous thymus-dependent and -independent antigens by mice with lupus syndromes. J. Immunol. 130 : 2161-2167, 1983.

24) Nozaki, Y., et al. : The beneficial effects of treatment with all-trans-retinoic acid plus corticosteroid on autoimmune nephritis in NZB/ WF mice. Clinical and Experimental Immunology. 139 : 74-83, 2005.

25) Kinoshita, K., et al. : Successful Treatment With Retinoids in Patients With Lupus Nephritis. Am. J. Kid. Dis. 55 : 344-347, 2010. 